\title{
Physiological quality and expression of genes in seeds of Handroanthus serratifolius subjected to drying ${ }^{1}$
}

\author{
Leandra Helena do Nascimento Gonçalves², Heloísa Oliveira dos Santos², \\ Édila Vilela de Resende Von Pinho ${ }^{2}$, Thaís de Andrade ${ }^{2 *}$, \\ Iolanda Vilela Von Pinho², Rucyan Walace Pereira ${ }^{2}$
}

\begin{abstract}
Handroanthus serratifolius seeds are considered orthodox and have some mechanisms that assist in desiccation tolerance, like heat-resistant proteins and the presence of protective systems against free radical production. In order to investigate the drying effect on the quality of Handroanthus serratifolius seeds collected with $28 \%$ water content two methods were used: slow drying $\left(30^{\circ} \mathrm{C}\right)$ and fast drying $\left(45^{\circ} \mathrm{C}\right)$ until water contents equaled $20 \%, 15 \%, 10 \%$ and $5 \%$. Seed quality was assessed by germination test, first count of germination, speed germination, emergence and speed emergence. The expression of heat-resistant proteins and enzymes catalase, esterase and isocitrate lyase was assessed by electrophoresis. The gene expression of sHSP17.5, CAT3 and ICL6 was quantified by real time PCR. Higher values of germination and vigor were obtained in seeds with $20 \%$ water content, subjected to fast drying. There was induction of heat-resistant proteins expression for both drying methods. There was variation in the electrophoretic pattern of catalase, esterase and isocitrate lyase in seeds subjected to different treatments. The gene expression in Handroanthus serratifolius seeds varies depending on methods of drying and water content of seeds. The drying of Handroanthus serratifolius seeds until the water content between 15 and $10 \%$ compromises their physiological quality.
\end{abstract}

Index terms: isoenzymes, enzymes, $q R T-P C R$, Handroanthus serratifolius.

\section{Qualidade fisiológica e expressão de genes em sementes de Handroanthus serratifolius submetidas à secagem}

\begin{abstract}
RESUMO - Sementes de ipê-amarelo são consideradas ortodoxas e dispõem de mecanismos que auxiliam na tolerância à dessecação, como proteínas resistentes ao calor e sistemas de proteção contra radicais livres. Para investigar o efeito da secagem na qualidade das sementes de ipê-amarelo coletadas com $28 \%$ de teor de água utilizaram-se dois métodos: secagem lenta $\left(30^{\circ} \mathrm{C}\right)$ e secagem rápida $\left(45^{\circ} \mathrm{C}\right)$ até atingirem teores de água na massa de sementes iguais a $20 \%, 15 \%, 10 \%$ e $5 \%$. A qualidade das sementes foi avaliada por meio de testes de germinação e vigor. Foi avaliada a expressão das proteínas resistentes ao calor e das enzimas catalase, esterase e isocitrato liase. A expressão dos genes sHSP17.5, CAT3 e ICL6 foi quantificada por meio da técnica de qRT-PCR. Maiores valores de germinação e vigor foram obtidos em sementes com teor de água de $20 \%$, submetidas à secagem rápida. Houve a indução de expressão de proteínas resistentes ao calor nos dois métodos de secagem. Ocorreu variação no padrão eletroforético das enzimas catalase, esterase e isocitrato liase entre os diferentes tratamentos. A expressão de genes varia em função dos métodos de secagem e teores de água das sementes. A secagem até os teores de água entre 15 e $10 \%$ compromete a qualidade fisiológica das mesmas.
\end{abstract}

Termos para indexação: isoenzimas, enzimas, $R T q P C R$, ipê-amarelo.

\section{Introduction}

In Brasil, Handroanthus serratifolius has been studied due to being a species of high economic, ornamental, medicinal and environmental value. The spread of Handroanthus serratifolius is done by seeds, which are produced in large quantities, but its indiscriminate exploitation has led to the decline of populations of this species (Grose and Olmstead, 2007).

In this context, the production of high quality Handroanthus serratifolius seeds is important for the formation of seedlings for reforestation, urban forestry, timber production, among other applications.

${ }^{1}$ Submitted on $12 / 23 / 2014$. Accepted for publication on $03 / 13 / 2015$.

${ }^{2}$ Departamento de Agricultura, UFLA, Caixa Postal 3037, 37200-000 - Lavras, MG, Brasil.

*Corresponding author <thaisandradeagro@gmail.com>

Journal of Seed Science, v.37, n.2, p.102-110, 2015 
Handroanthus serratifolius seeds are considered orthodox, i.e., they exhibit tolerance to desiccation and may be dehydrated for storage, although they present variations in germination percentage in such conditions (Souza et al., 2005).

Desiccation tolerance has been attributed to a number of mechanisms involving, among other factors, the synthesis of sugars, presence of protection systems against the production of free radicals during desiccation and the production of heatresistant proteins (Leprince and Buitink, 2010).

The response to dehydration of orthodox seeds is influenced by the drying rate, as well as desiccation tolerance of vegetative tissues. Increased tolerance to desiccation of seeds is observed in slow drying, presumably due to the time allowed for the induction and operation of protection mechanisms. Fast drying prevents recovery processes, requiring more time for repairs in rehydration (Hand et al., 2011).

The expression of heat-resistant proteins of different classes has been one of the most studied mechanisms in the adaptation of organisms to a stress condition. These proteins are highly conserved and participate in various cellular processes in different tissues and developmental stages, such as the group of proteins known as LEA (Late Embryogenesis Abundant), which are encoded by genes expressed during the maturation and drying phases of seed (Porcel et al., 2005).

Studies related to the mechanism of desiccation tolerance in forest seeds at the molecular level are scarce. Using molecular techniques it is possible to improve the understanding of biochemical characteristics associated with desiccation tolerance and seed quality.

Therefore, the aim in this study was to assess the physiological quality and gene expression of Shsp17.5, ISO6 and CAT3 in seeds of Handroanthus serratifolius subjected to drying.

\section{Material and Methods}

The survey was conducted in the nursery of forest species at Department of Forest Sciences and Central Laboratory of Seeds of the Department of Agriculture of the Federal University of Lavras, in the Brazilian city of Lavras, MG. The fruits of Handroanthus serratifolius were collected from 13 trees located on the campus of UFLA. Data collection was performed using a trimmer and the fruits were supported on plastic canvas so that there was contact with the ground. The seeds were manually removed by the longitudinal section by a slight twist of the fruits and homogenized in a burlap sack, forming a single batch. After extraction of the seeds, the initial water content was assessed by the greenhouse method at $105 \pm 3{ }^{\circ} \mathrm{C}$ for 17 hours (Brasil, 2009).

The seeds were dried in experimental dryers, regulated at $30{ }^{\circ} \mathrm{C}$ for slow drying and $45{ }^{\circ} \mathrm{C}$ for fast drying. During the process the seeds were turned and drying was stopped when they reached $20 \%, 15 \%, 10 \%$ and $5 \%$ water content. As a control seeds without drying were used, with $28 \%$ water content. The water content of the seeds of all samples was confirmed by the oven method at $105 \pm 3{ }^{\circ} \mathrm{C}$ for 17 hours (Brasil, 2009). Soon after drying a quality assessment by means of germination, vigor and water content tests was performed. Part of the seeds was stored in deep freezer at $-84{ }^{\circ} \mathrm{C}$ for later analysis of the expression of proteins and isoenzymes.

The germination test was conducted according to the Regras para Análise de Sementes (Rules for Seeds Analyses) (RAS) (Brasil, 2009). Along with the germination test, the first count of germination test was conducted and also the germination rate index was assessed, according to the expression proposed by Edmond and Drapala (1958).

An emergence test was performed under controlled conditions (germination chamber with controlled temperature at $25{ }^{\circ} \mathrm{C}$, relative humidity of $80 \%$ and continuous light), with four replications. To calculate the emergence speed index (ESI) the formula by Edmond and Drapala (1958) was used. The seedling emergence assessment in environmental conditions was also analyzed.

For the analysis of the results of the assessments of the physiologic quality, the completely randomized design in a factorial scheme $[(2 \times 4)+$ control $]$ was used, being two drying methods (slow drying $30{ }^{\circ} \mathrm{C}$ and fast drying $45^{\circ} \mathrm{C}$ ), four water content levels $(20 \%, 15 \%, 10 \%$ and $5 \%)$ and (additional) control with 28\% water content. Software Assistat Version 7.5 Beta was used and the means were compared by the ScottKnott test at 5\% probability. By means of the same software, the Dunnantt test was used to compare the means of the interaction between each factor and the control means, at 5\% probability.

For the assessment of heat-resistant proteins, $100 \mathrm{mg}$ of seeds were ground in a mortar with liquid nitrogen, placed in $2 \mathrm{~mL}$ microtubes with $1800 \mu \mathrm{L}$ of an extraction buffer (50 $\mathrm{mM}$ tris-HCl-7.5; $500 \mathrm{mM} \mathrm{NaCl} ; 5 \mathrm{mM} \mathrm{MgCl}$; 1 mM PMSF) and shaken in Vortex. The homogenate was centrifuged at $14,000 \mathrm{rpm}$ for 20 minutes at $4{ }^{\circ} \mathrm{C}$, the supernatant collected and incubated in a water bath at $80{ }^{\circ} \mathrm{C}$ for 10 minutes and centrifuged again. The supernatant was poured into microtubes, and the pellet was discarded. $57 \mathrm{uL}$ of sample buffer solution $(0.5 \mathrm{mM}$ glycerol, $1 \mathrm{mM}$ of SDS, $5 \mathrm{mM}$ of bromophenol blue and the volume completed to $20 \mathrm{~mL}$ of extraction buffer) were added to the sample tubes containing $100 \mu \mathrm{L}$ of protein extract, and then they were placed in a water bath with boiling water for five minutes. $50 \mathrm{uL}$ of each sample 
were applied to SDS-PAGE polyacrylamide gel at $12.5 \%$ (separating gel) and 6\% (stacking gel) and electrophoresis was carried out at 150 Volts. Gels were stained with $0.05 \%$ Coomassie blue as described by Alfenas et al. (2006), for 18 hours and destained in $10 \%$ acetic acid solution.

For the extraction of the enzymes, buffer Tris HCL 0.2 $\mathrm{M} \mathrm{pH} 8.0+(0.1 \%$ mercaptoethanol $)$ was used in a ratio of $250 \mathrm{uL}$ per $100 \mathrm{mg}$ of seeds ground in liquid nitrogen. The material was homogenized and kept overnight in the refrigerator, followed by centrifugation at $14,000 \mathrm{rpm}$ for 30 minutes at $4{ }^{\circ} \mathrm{C} .60 \mathrm{uL}$ of supernatant of the samples were administered in polyacrylamide gel in a discontinuous system (7.5\% separating gel and 4.5\% stacking gel). Gels were developed enzymes for catalase, esterase and isocitrate lyase, according to Alfenas et al. (2006).

For the qRT-PCR (Reverse transcription polymerase chain reaction) technique, the expression of genes encoding heat shock proteins and enzymes isocitrate lyase and catalase was assessed because these have their known importance in the process of seed germination and drying.

RNA extraction from the seeds with and without drying was performed, macerated in the presence of liquid nitrogen with the addition of reagent Pure Link RNA Plant ${ }^{\mathbb{B}}$ (Invitrogen), according to the manufacturer's specifications. The integrity and purity of RNA were assessed in all stages with the use of electrophoresis in agarose gel and in a spectrophotometer (NanoVue).

After extraction of the nucleic acids, the samples were treated with Kit DNAse Turbo Free ${ }^{\circledR}$ AMBIOM to avoid any contamination with DNA. The purified messengers RNA were used as a template for cDNA synthesis. Kit High Capacity cDNA Reverse Transcription cDNA $^{\circledR}$ (Applied Biosystems) was used, according to the protocol recommended by the manufacturer. The efficiency of the cDNA synthesis was confirmed by a conventional PCR.

The sequences of the chosen target genes were found by searching the GenBank, and the primers used for amplification of the target regions were drawn up using software Primer Express 3.0 (Applied Biosystems). The sequences of the primers are shown in Table 1. As endogenous control were used the genes for $18 \mathrm{~s}$ and GAPDH (glyceraldehyde-3phosphate dehydrogenase).

Table 1. Proteins studied in the analysis of qRT-PCR and sequencing of primers designed from GenBank information.

\begin{tabular}{lll}
\hline \multicolumn{1}{c}{ Gene } & & \multicolumn{1}{c}{ Sequence 5'---------3' } \\
\hline \multirow{2}{*}{ Small heat shock proteins (sHSP17.5) } & $\mathrm{F}$ & AGGGCTGAAGAAAGAGAAAGTCAGG \\
\multirow{2}{*}{ Isocitrate lyase (ISO6) } & $\mathrm{R}$ & TTTTCCATCGCTGCCTTCACG \\
\multirow{2}{*}{ Catalase (CAT3) } & $\mathrm{F}$ & GGGCATGAGCCGTGAAGA \\
& $\mathrm{R}$ & CAATGATGGGCTTCAAGTAATCAA \\
$18 \mathrm{~s}$ & $\mathrm{~F}$ & TGACTGCCACACGATCATCTTC \\
& $\mathrm{R}$ & CGGGAGGCAGTGGGAAA \\
Glyceraldehyde-3-phosphate dehydrogenase (GAPDH) & $\mathrm{F}$ & TGACGGAGAATTAGGGTCG \\
& $\mathrm{R}$ & CCTCCAATGGATCCTCGTTA \\
& $\mathrm{F}$ & ATGATGATGTGAAAGCAGCG \\
\hline
\end{tabular}

(F) sequencing of forward and (R) sequencing of primer reverse.

qRT-PCR was performed in an appliance of real-time PCR System 7500 (Applied Biosystems) using SYBR ${ }^{\circledR}$ Green PCR Master Mix (Applied Biosystems) and the samples of cDNA synthesized from the extracted RNA. The reaction amplification conditions were $2 \mathrm{~min}$ at $50{ }^{\circ} \mathrm{C}, 10$ minutes at $95{ }^{\circ} \mathrm{C}$, followed by 40 cycles of 15 seconds at $95{ }^{\circ} \mathrm{C}$ and 1 minute at $60{ }^{\circ} \mathrm{C}$, and ended with 15 seconds at $95{ }^{\circ} \mathrm{C}$. For each reaction were used $30 \mathrm{ng}$ of cDNA, $0.4 \mu \mathrm{M}$ of each primer and $250 \mu \mathrm{M}$ of Master Mix SYBR green UDG with ROX (Invitrogen) for a final volume of $10.0 \mu \mathrm{L} /$ sample. Negative controls, consisting of water, and endogenous controls were included in every analysis. All reactions were performed in triplicate. Data collection was performed using software v. 2.0.1, of system 7500 of PCR in real time (Applied Biosystems). The comparative $C t$ method for relative quantification was used, where the $C t$ s (cycle threshold) of the samples were normalized using the $C t$ s of the endogenous controls.

The samples corresponding to the seeds nonsubjected to drying were considered as calibrators. For the quantification of the gene expression by the PCR technique in real time, the obtained values corresponding to the levels of mRNAs of the samples were compared to the values of the levels of mRNAs of the controls. The raw data were analyzed using computer program 7500 Software SDS (Version 2.0.1). 


\section{Results and Discussion}

The mass of seeds water content at the end of the drying process and the time spent in this operation are shown in Table 2. Shorter drying time in the drying was observed at $45{ }^{\circ} \mathrm{C}$, regardless of the final water content of the seeds. It is noteworthy that the time taken to reduce the water content to $5 \%$ was twice as much for the slow drying $\left(30^{\circ} \mathrm{C}\right)$ compared to the last drying. Zonta et al. (2011), when drying Jatropha curcas L. (common names include Barbados nut, purging nut, physic nut, or JCL (abbreviation of Jatropha curcas L.) seeds also observed a reduction in drying time with increasing temperature.

Regarding the results of germination and vigor tests, there was a significant interaction between the drying method and water content for the germination speed index (GSI), emergence speed index (ESI), emergence percentage of seedlings and emergence of seedlings in the field.

The highest germination values were observed in the seeds of Handroanthus serratifolius subjected to fast drying, regardless of seed water content (Table 3 ).

Table 2. Water content and final drying time of Handroanthus serratifolius seeds according to the drying method.

\begin{tabular}{ccc}
\hline \multirow{2}{*}{ Final water content } & \multicolumn{2}{c}{ Drying method } \\
\cline { 2 - 3 } & Slow $\left(30^{\circ} \mathrm{C}\right)$ & Fast $\left(45^{\circ} \mathrm{C}\right)$ \\
\hline $20 \%$ & $1 \mathrm{~h} 13 \mathrm{~min}$ & $53 \mathrm{~min}$ \\
$15 \%$ & $2 \mathrm{~h} 53 \mathrm{~min}$ & $1 \mathrm{~h} 25 \mathrm{~min}$ \\
$10 \%$ & $3 \mathrm{~h} 53 \mathrm{~min}$ & $2 \mathrm{~h} 10 \mathrm{~min}$ \\
$5 \%$ & $6 \mathrm{~h} 15 \mathrm{~min}$ & $3 \mathrm{~h} 16 \mathrm{~min}$ \\
\hline
\end{tabular}

Table 3. Percentage of germination and germination first count of seeds of Handroanthus serratifolius subjected to slow $\left(30^{\circ} \mathrm{C}\right)$ and fast $\left(45^{\circ} \mathrm{C}\right)$ drying.

\begin{tabular}{ccc}
\hline Drying & Germination & First count \\
\hline Slow & $87 \mathrm{~b}$ & $70 \mathrm{~b}$ \\
Fast & $94 \mathrm{a}$ & $81 \mathrm{a}$ \\
\hline CV $(\%)$ & 5.38 & 10.22 \\
\hline
\end{tabular}

Means followed by the same capital letter in the row and lowercase letter in the column do not differ by Scott-Knott test at 5\% probability.

In some species, higher germination has been reported when using a process of fast drying, like in the results obtained by Zonta et al. (2011) for Jatropha curcas seeds. Seeds dried slowly, probably because they stay for a longer period with a high water content, have an accelerated deterioration process, leading to loss of germination. Similar results were found by Carvalho et al. (2008), in Handroanthus serratifolius seeds with $80 \%$ humidity that showed $20 \%$ germination. Gemaque et al. (2005) suggest that the loss in water content is a prerequisite for the synthesis of new enzymes and proteins, which participate in the metabolic process or in the processes that allow for the germination and growth.

Avelar et al. (2011) state that the maximum temperature for the safe drying of seeds is dependent on the species, but generally ranges between 35 and $45^{\circ} \mathrm{C}$, and for partially dry seeds this temperature may be higher. Barbedo and MarcosFilho (1998) have subjected Caesalpinia echinata (common names include Brazilwood, Pau-Brasil, Pau de Pernambuco, Pernambuco tree, Nicaragua wood and Ibirapitanga (Tupi)) seeds to drying in greenhouses regulated at 40 and $50{ }^{\circ} \mathrm{C}$, reducing the water content up to $8 \%$, and have found no drying temperature effect on seed germination.

Regarding the effect of drying on seed germination, it was found that among the drying methods, fast drying promoted the greatest percentage of germination in the first count (81\%), regardless of the degree of seed water content (Table 3 ) .

The germination rate index was similar in all water content levels and did not differ from control, except in the seeds with $10 \%$ water content in the slow drying (Table 4). The speed and uniformity of germination are desirable characteristics, because the longer the seedling remains in the early stages of development, the more it shall be subject to adverse environmental conditions, including being susceptible to fungi often present in Handroanthus serratifolius seeds (Botelho et al, 2008).

Table 4. Germination speed index (GSI) of Handroanthus serratifolius seeds subjected to the slow and fast drying and control treatment.

\begin{tabular}{ccccc}
\hline \multirow{2}{*}{ Drying } & \multicolumn{5}{c}{ Water content of the seeds (\%) } \\
\cline { 2 - 5 } & 20 & 15 & 10 & 5 \\
\hline Slow & $7 \mathrm{a}$ & $7 \mathrm{a}$ & $8 \mathrm{r}$ & $7 \mathrm{a}$ \\
Fast & $6 \mathrm{a}$ & $7 \mathrm{a}$ & $7 \mathrm{a}$ & $7 \mathrm{a}$ \\
\hline Control & \multicolumn{5}{c}{$6 \mathrm{a}$} \\
\hline CV $(\%)$ & \multicolumn{5}{c}{5.68} \\
\hline
\end{tabular}

$\gamma$ Means differ from the control, at $5 \%$ probability by Dunnett's test.

The shorter periods for seedling emergence have occurred in seeds non-subjected to drying (control with 28\% humidity), not differing from the treatments with water content of $20 \%$ and $15 \%$ in fast drying (Table 5).

The seeds with higher water contents tend to germinate faster because they demand less time in the soaking process, which reflects on the emergence speed index. The percentage of emergence reduction was observed for the seedlings when the seeds were subjected to fast drying with water content of $15 \%$ (Table 6). This behavior was similar to the one found by Gentil (2001), who, by drying coffee beans at a temperature 
of $30{ }^{\circ} \mathrm{C}$, has observed an inferiority in the performance of the seeds with $16 \%$ humidity in relation to the ones that presented $10 \%$ and $34 \%$.

Table 5. Seedling emergence speed index (ESI) derived from Handroanthus serratifolius seeds subjected to the slow and fast drying and without drying (control).

\begin{tabular}{ccccc}
\hline \multirow{2}{*}{ Drying } & \multicolumn{5}{c}{ Water content of the seeds (\%) } \\
\cline { 2 - 5 } & 20 & 15 & 10 & 5 \\
\hline Slow & $7 \mathrm{bAr}$ & $7 \mathrm{bAr}$ & $7 \mathrm{bAr}$ & $7 \mathrm{bAr}$ \\
Fast & $6 \mathrm{aA}$ & $6 \mathrm{aA}$ & $7 \mathrm{bB} \gamma$ & $7 \mathrm{bB}$ \\
\hline Control & \multicolumn{5}{c}{6} \\
\hline CV $(\%)$ & \multicolumn{5}{c}{5.52} \\
\hline
\end{tabular}

Means followed by the same capital letter in the row and lowercase letter in the column do not differ by Scott-Knott test at 5\% probability. $r$ Means differ from the control, at $5 \%$ probability by Dunnett's test.

Table 6. Estimates of the emergence percentage values of seedlings derived from Handroanthus serratifolius seeds subjected to slow and fast drying and without drying (control).

\begin{tabular}{crrrr}
\hline \multirow{2}{*}{ Drying } & \multicolumn{4}{c}{ Water content of the seeds (\%) } \\
\cline { 2 - 5 } & \multicolumn{1}{c}{15} & 10 & 5 \\
\hline Slow & $96 \mathrm{bA}$ & $99 \mathrm{aA}$ & $100 \mathrm{aA}$ & $97 \mathrm{aA}$ \\
Fast & $100 \mathrm{aA}$ & $95 \mathrm{bB}$ & $98 \mathrm{aA}$ & $98 \mathrm{aA}$ \\
\hline Control & \multicolumn{5}{c}{96} \\
\hline CV (\%) & \multicolumn{5}{c}{2.56} \\
\hline
\end{tabular}

Means followed by the same capital letter in the row and lowercase letter in the column do not differ by the Scott-Knott test at $5 \%$ probability.

Unlike the results obtained in the tests conducted in conditions favorable for germination and emergence, the highest percentages of emergence of seedlings in the field, compared to the control, were observed in seeds with 15 and $10 \%$ water content, regardless of the drying and $5 \%$ water content in the slow drying (Table 6).

These results can be attributed to the harsh conditions imposed by the environment. The seeds with higher water content are more prone to the action of microorganisms in soil, which may affect the germination and consequently the emergence.

The electrophoretic patterns of the heat-resistant proteins of the seeds undergoing fast and slow drying are shown in Figure 1. The presence of bands that are characteristic of the heat-resistant proteins is observed in seeds subjected to different treatments, demonstrating desiccation tolerance, irrespective of the drying method used, as shown for the bands identified with a molecular weight between 40 and 15 $\mathrm{kDa}$. It is possible that some $L E A$ proteins have a dual role during the plant life cycle, functioning as a storage protein during germination and also in desiccation tolerance during seed development (Manfre et al., 2009). Between the fast and slow drying processes, an enhanced expression of heatresistant protein was found in seeds undergoing fast drying (TA, TB, TC and TD). This suggests that the temperature of $45^{\circ} \mathrm{C}$ may have induced the expression of these proteins in Handroanthus serratifolius seeds. However, it is emphasized that these analyses are subjective and therefore the use of more sensitive techniques must be applied, like the gene expression technique encoding these proteins.

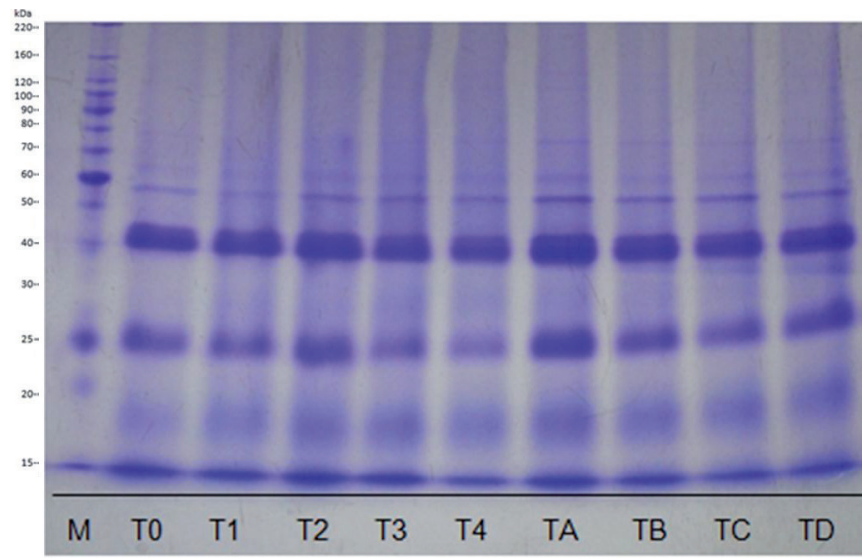

Figure 1. Electrophoretic pattern of heat-resistant proteins in Handroanthus serratifolius seeds subjected to slow drying $\left(30^{\circ} \mathrm{C}\right)$, humidities $\mathrm{T} 1-20 \%$, T2-15\%, T3-10\%,T4-5\%; fast drying $\left(45{ }^{\circ} \mathrm{C}\right)$, humidities: TA-20\%, TB- $15 \%$, TC-10\%, TD- $5 \%$ and without drying, humidity T0-28\%; M - Protein Molecular Weight Marker.

The heat-resistant proteins have been implicated as one of the mechanisms developed by the seeds to protect and repair cellular structures exposed to desiccation and subsequent soaking. According to Boucher et al. (2010) an important feature of survival in the dry state is the ability to protect the membranes in transition, preventing the loss of integrity. This role has been attributed to the heat-resistant proteins such as heat shocks, deidrines and $L E A$ proteins. This protection capability is possible due to their highly hydrophilic characteristic that seems to be linked to their occurrence in specific cellular structures (Macherel et al., 2007).

Regarding enzymatic activity, the seeds with higher water content and those that were not subjected to drying have shown no activity of catalase (Figure 2). In the wet seeds, the repair mechanisms that include free radical scavenger enzymes are not triggered, which was confirmed by the lack of activity of this enzyme in the seeds that were not subjected to drying. 

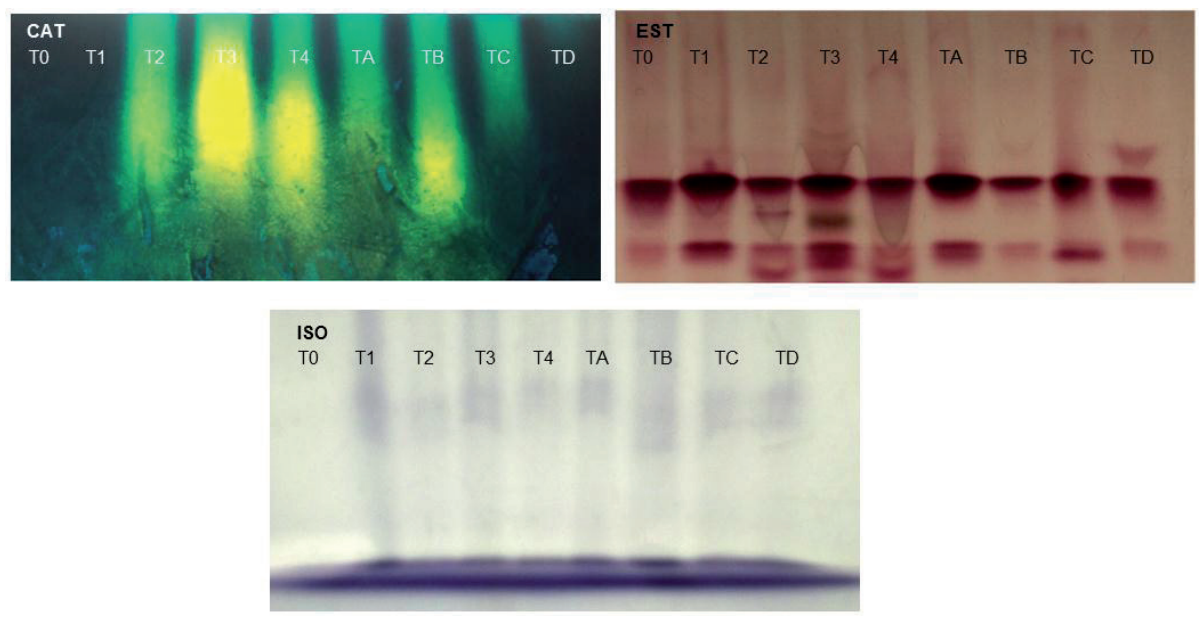

Figure 2. Electrophoretic pattern of catalase enzymes (CAT), esterase (EST) and isocitrate lyase (ISO) in Handroanthus serratifolius seeds subjected to slow drying $\left(30{ }^{\circ} \mathrm{C}\right)$, humidities $\mathrm{T} 1-20 \%$, T2-15\%, T3-10\%, T4-5\%; fast drying (45 ${ }^{\circ} \mathrm{C}$ ), humidities: TA-20\%, TB-15\%, TC-10\%,TD-5\% and without drying, humidity T0-28\%.

Increased activity of enzyme catalase was observed in seeds subjected to slow drying (T2, T3 and T4). In these treatments, the seeds remained for longer periods in hydration levels which allow the occurrence of deteriorative reactions, including those caused by free radicals, leading to oxidative damage (Pammenter et al., 1998).

These results are comparable to those observed in the germination test and in the germination first count test (Table 3 ), in which were found lower values than those observed in treatments whose seeds were subjected to fast drying.

Damage caused by desiccation have been related to the formation of reactive oxygen species (ROS) as a result of the unbalanced metabolism. The ROSs react with cellular macromolecules causing damage and function disorders of the cells. In deterioration of the seeds there is increase in lipid peroxidation, which results in membrane damage and generation of toxic by-products (Schwember and Bradford, 2010).

Probably, the increase in catalase activity observed in the seeds with $15 \%$ water content subjected to fast drying (Figure 2) is due to damage caused by desiccation. In seeds subjected to this treatment, a smaller percentage of seedling emergence was observed (Table 6).

The oxidative stress that is caused is counteracted by a complex antioxidant defense system, related to an increased production and activation of metalloenzymes, among which is catalase (CAT) (Scandalios, 2005; Fagagna, 2008). During the process of seed deterioration, there is a decrease in enzyme activity by its progressive inactivation or reduction and stoppage of its synthesis (Marcos-Filho, 2005). According to Demirkaya et al. (2010), general decrease in CAT activity in the seed slows the breathing capacity by reducing the supply of energy (ATP; adenosine triphosphate) and similar, for seed germination.

Regarding esterase enzyme, it showed greater activity in seeds subjected to slow drying and also between these treatments it was possible to observe the appearance of isoforms that differentiate the seeds dried up to the water contents of $15 \%$ and $10 \%$. According to Silva et al. (2011) esterase is possibly a rather sensitive enzyme, and the electrophoretic profile is much altered, mainly by interference from external factors.

The changes in the pattern of this enzyme may be associated with deteriorative events. Thus, as described above for catalase, the remaining seeds in the drying process for a longer period may have caused damage to the membranes.

Esterase is involved in the hydrolysis of esters and lipid metabolism, and these events are associated with membrane damage and reduction in germination (Basavarajappa et al., 1991). These results corroborate those observed in the germination test and in the germination first count test, in which were observed smaller germination values in seeds subjected to slow drying (Table 3 ).

Also relating the expression of esterase to the physiological tests, slower germination of seeds subjected to slow drying at $10 \%$ water content can be observed, coinciding with an increased enzyme activity in seeds subjected to this treatment.

With respect to the expression of the enzyme isocitrate lyase by means of the electrophoresis technique it was possible to identify only low molecular weight band (Figure 2). In the control treatment, which consists of seeds without drying, is was not possible to detect activity of this enzyme. In the treatments undergoing slow drying there is a greater expression of isocitrate lyase in the seeds with water content 
of $20 \%$, followed by $10 \%$.

As for the fast drying, an enhanced expression in seeds at $15 \%$ water content was observed, a result that can be related to the seed vigor, since in seeds in this condition significant values for the emergence speed index were observed (Table 5).
By the results obtained by the expression of genes associated with the heat-resistant protein coding SHSP17.5 and of enzymes catalase (CAT) and isocitrate lyase (ICL), there is a variation in the expression of these genes in all treatments (Figure 3).
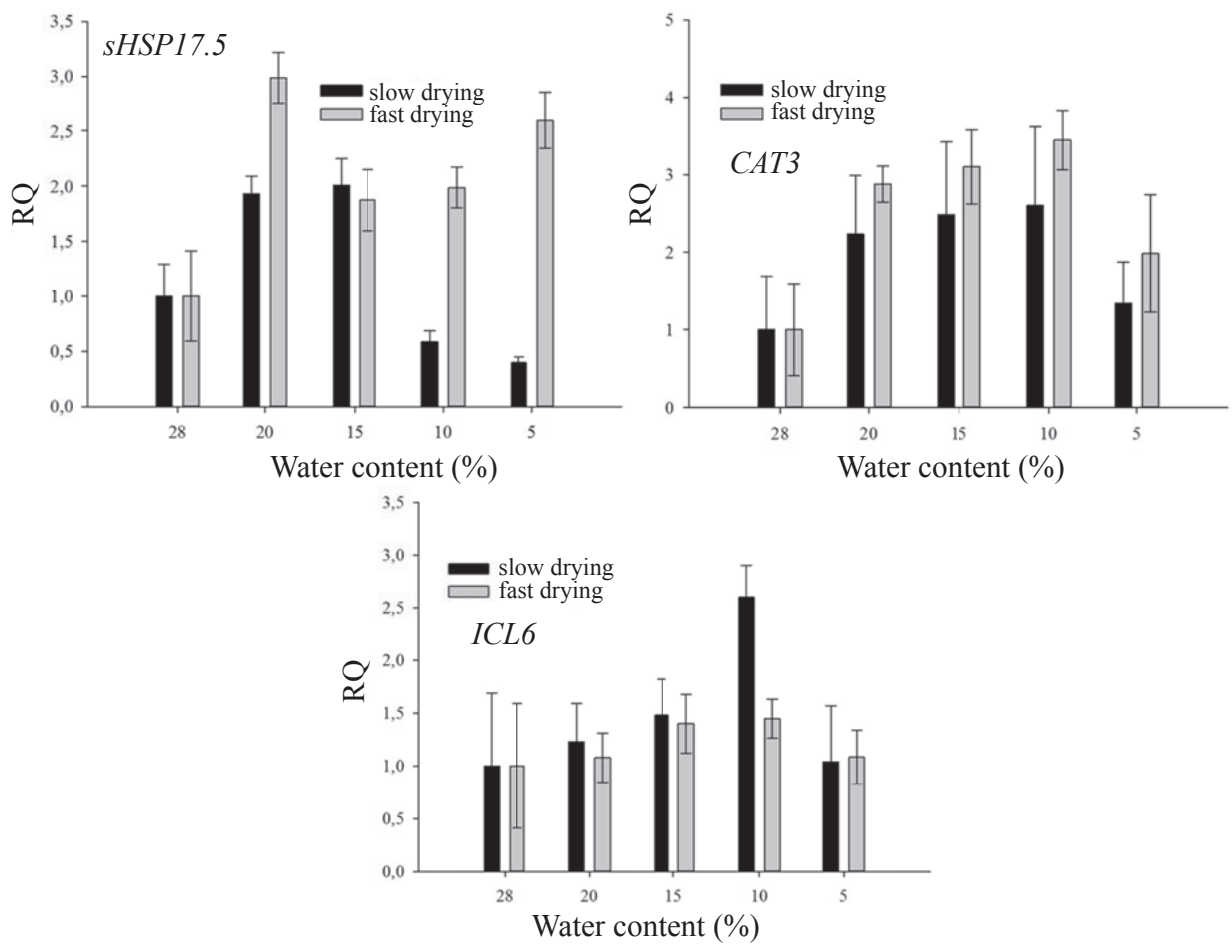

Figure 3. Profile of the relative quantitative expression of genes sHSP17.5, catalase (CAT3) and isocitrate lyase (ICL6) in Handroanthus serratifolius seeds with a water content of $28 \%$ (control) and of seeds subjected to slow and fast drying, with water content equal to $20 \%, 15 \%, 10 \%$ and $5 \%$, with variation bars for the standard deviation between repetitions.

Greater expression of gene sHSP17.5 was observed in seeds subjected to fast drying. For slow drying, the expression of this gene was higher in seeds with higher water content (20 to $15 \%$ ) and for seeds with lower water levels (10 and 5\%) their expression was lower than the control (28\%) used as a calibrator.

Gene sHSP17.5 expression values obtained by the relative quantification of the seeds subjected to fast drying in the treatments of 20 and $5 \%$ water content, where there are the maximum expressions, are higher than those observed in slow drying. And lower expression of this gene has been observed in slow drying at $5 \%$.

Possibly, the fast drying induced sHSP17.5 gene expression, as can be observed in the relative quantification values compared to the values obtained for the control without drying. This behavior can also be observed in the electrophoretic pattern of heat-resistant proteins (Figure 1) with the highest expression in TA treatments (fast drying, $20 \%$ water content) and TD (fast drying, 5\% water content).
The heat shock proteins are broken down into low molecular weight proteins of approximately 15-28 kDa ( $s H S P s)$ and proteins of high molecular weight over $30 \mathrm{kDa}$ (HMM HSPS); $s H S P$ s have been discovered as products of genes whose expression is induced by heat and other forms of abiotic stress (José et al., 2005).

For CAT3 gene (Figure 3), associated with encoding catalase enzyme, the relative quantitative expression was higher than the control for all treatments in both slow and the fast drying.

In the slow and fast drying, an increased expression of gene CAT3 was observed as the water content of the seeds was reduced to $10 \%$, and reduced expression with drying up to $5 \%$. Probably the increased expression of this gene is a form of protection of the seeds to respond faster to the stress caused by drying. However, when there is a reduction in the production of such transcripts, as observed in the $5 \%$ of water content, it is possible to relate to the unnecessary expense of metabolic energy. These results may help to understand why there was 
no activity of catalase isoenzyme in treatments at $28 \%$ without drying and 5\% water content in fast drying (Figure 2).

Regarding the expression of the isocitrate lyase gene, this one has increased with drying in relation to the control when the seeds were dried slowly and fast to the water contents of 20,15 and $10 \%$, with reduced expression in dry seeds to $5 \%$ water content.

It can be noted that the pattern of expression of gene ICL6 is similar to the expression of CAT3 gene in absolute values. Comparing all treatments assessed, there was a significant expression of gene ICL6 in seeds subjected to slow drying and with $10 \%$ water content.

Isocitrate lyase is a key enzyme in the regulation of the glyoxylate cycle and involved in the metabolism of lipids stored in oil seeds, and in the development of activities in glyoxysomes. The activity of this enzyme increases during the germination of seeds, obtaining maximum values when there is the maximum proportion of degraded lipids and in sucrose synthesis (Bewley and Black, 1994). It is noteworthy that, in analyzing the chemical composition of Handroanthus serratifolius seeds held by Freitas et al. (1979), there was an average composition of $8.36 \%$ of carbohydrates, $7.0 \%$ of proteins and $28.68 \%$ of oil, justifying such results.

Given the above, when comparing the results of expression of gene ICL6 and of the results observed in the physiological tests on seeds subjected to slow drying and with $10 \%$ water content, it is inferred that lipid oxidation in seeds subjected to these conditions may have occurred.

\section{Conclusions}

The expression of heat-resistant proteins and enzymes catalase, esterase and isocitrate lyase in Handroanthus serratifolius seed varies according to the drying methods and seed water content.

Drying of Handroanthus serratifolius seeds in the intermediate water contents (15 and 10\%) compromises their physiological quality, regardless of the drying being fast or slow.

Fast drying favors the germination of Handroanthus serratifolius for all tested water content.

Slow drying compromises the quality of Handroanthus serratifolius seeds.

\section{References}

ALFENAS, A. C. Eletroforese e marcadores bioquímicos em plantas e microorganismos. Viçosa, MG: UFV, 2006. 627 p.

AVELAR, S.A.G.; LEVIEN, A.M.; PESKE, S.T.; VILLELA, F.A.; BAUDET, L. Secagem estacionária de sementes de soja com ar desumidificado por resfriamento. Revista Brasileira de Sementes, v.33, n.3, p.454-462, 2011. http://www.scielo.br/pdf/rbs/v33n3/08.pdf
BARBEDO, C.J.; MARCOS-FILHO, J. Tolerância à dessecação em sementes. Acta Botânica Brasílica, v.12, n.2, p.145-164, 1998. http://www. scielo.br/scielo.php?script=sci_arttext\&pid=S0102-33061998000200005

BASAVARAJAPPA, B.S.; SHETTY, H.S.; PRAKASH, H.S. Membrane deterioration and other biochemical chances, associated with accelerated ageing of maize seeds. Seed Science and Technology, v.19, n.2, p.279286, 1991. http://eprints.uni-mysore.ac.in/7247/

BEWLEY, J.D.; BLACK, M. Seeds: physiology of development and germination. 2d ed. New York: Plenum, 1994. 445p.

BOTELHO, L.B.; MORAES, M.H.D.; MENTEN, J.O.M. Fungos associados às sementes de ipê-amarelo (Tabebuia serratifolia) e ipê-roxo (Tabebuia impetiginosa): incidência, efeito na germinação e transmissão para as plântulas. Summa Phytopathologica, v.34, n.4, p.343-348, 2008. http://www.scielo.br/pdf/sp/v34n4/v34n4a08.pdf

BOUCHER, V.; BUITINK, J.; LIN, X.; HOEKSTRA, F.A.; HUNDERTMARK, M.; RENARD, D.; LEPRINCE, O. MtPM25 is an atypical hydrophobic late embryogenesis-abundant protein that dissociates cold and desiccation-aggregated proteins. Plant Cell and Environment, v.33, n.3, p. 418-430, 2010. http://www.researchgate. net/publication/40680247_MtPM25_is_an_atypical_hydrophobic late_embryogenesis-abundant_protein_that_dissociates_cold_and_ desiccation-aggregated_proteins

BRASIL. Ministério da Agricultura, Pecuária e Abastecimento. Regras para análise de sementes. Ministério da Agricultura, Pecuária e Abastecimento. Secretaria de Defesa Agropecuária. Brasília: MAPA/ ACS, 2009. 395p. http://www.agricultura.gov.br/arq_editor/file/2946_ regras_analise_sementes.pdf

CARVALHO, M.L.M.; NERY, M.C.; OLIVEIRA, L.M.; HILHORST, H.W.M.; GUIMARÃES, R.M. Morphophysiological development of Tabeluia serratifolia. Vahl Nich. Scientia Agricola, v.65, n.6, p.643-651, 2008. http://www.scielo.br/pdf/sa/v65n6/12.pdf

DEMIRKAYA, M.; DIETZ, K.J.; SIVRITEPE, H.O. Changes in antioxidant enzymes during aging of onion seeds. Notulae Botanicae Horti Agrobotanici Cluj, v.38, n.1, p.49-52, 2010. http://www. notulaebotanicae.ro/index.php/nbha/article/view/4575

EDMOND JB.; DRAPALA, W.J. The effects of temperature, sand and soil, and acetone on germination of okra seed. Proceedings of the American Society of Horticutural Science, v.71, p.428-434, 1958. http:// www.scielo.br/scielo.php?script=sci nlinks\&ref $=000099 \&$ pid $=$ S0101$3122200600030001600016 \& \operatorname{lng}=\mathrm{pt}$

FAGAGNA, F.D. Living on a break: cellular senescence as a DNAdamage response. Nature Reviews, v.8, n.1, p.512-522, 2008.

FREITAS, S.C.; CANDIDO, J.F.; CONDE, A.R.; HARA, T. Determinação de equilíbrio higroscópico e viabilidade de sementes de ipê-amarelo (Tabebuia serratifolia (Vahl) Nichols) armazenadas em diferentes umidades relativas. Revista Árvore, v.3, n.2, p.135-144, 1979. http://books.google.com.br/books?hl=pt-BR\&lr=\&id=U0WaAAAAIA AJ\&oi=fnd\&pg $=$ PA135\&ots $=$ bFfE-J5z7e\&sig=IwxkTf5kgm7Pd2FHA eSQ3MWetVY\#v $=$ onepage \&q\& $\mathrm{f}=$ false

GEMAQUE, R.C.R.; DAVIDE, A.C.; SILVA, E.D.; FARIA, J.M.R Efeito das secagens lenta e rápida em sementes de ipê-roxo (Tabebuia impetiginosa (Mart.) Standl.). Cerne, v.11, n.4, p.329-335, 2005. http:/ www.dcf.ufla.br/cerne/artigos/11-02-20091585v11_n4_artigo\%2002.pdf 
GENTIL, D.F.O. Conservação de sementes do cafeeiro: resultados discordantes ou complementares. Bragantia, v.60, n.3, p.149-154, 2001. http://www.scielo.br/pdf/brag/v60n3/a01v60n3.pdf

GROSE, S.O.; OLMSTEAD, R.G. Taxonomic revisions in the polyphyletic genus Tabebuia s. 1. (Bignoniaceae). Systematic Botany, v.32, p.660-670, 2007. http://www.bioone.org/doi/abs/10.1600/036364407782250652

HAND, S.C.; MENZE, M.A.; TONER, M.; BOSWELL, L.; MOORE, D. LEA proteins during water stress: not just for plants anymore. Annual Review of Physiology, v.73, p.115-134, 2011. http://www.annualreviews. org/doi/full/10.1146/annurev-physiol-012110-142203

JOSÉ, S.C.B.R.; VON PINHO, E.V.R.; VON PINHO, R.G.; SILVEIRA, C.M. Padrão eletroforético de proteínas resistentes ao calor em sementes de milho. Pesquisa Agropecuária Brasileira, v.40, n.2, p.115-121, 2005. http://www.scielo.br/pdf/pab/v40n2/23817.pdf

LEPRINCE, O.; BUITINK, J. Desiccation tolerance: from genomics to the field. Plant Science, v.179, p.554-564, 2010. http://www. sciencedirect.com/science/article/pii/S0168945210000415

MACHEREL, D.; BENAMAR, A.; AVELANGE-MACHEREL, M.H.; TOLLETER, D. Function and stress tolerance of seed mitochondria. Physiologia Plantarum, v.129, p.233-241, 2007. http://www. readcube.com/articles/10.1111\%2Fj.1399-3054.2006.00807.x?r3 referer=wol\&tracking_action=preview_click\&show_checkout=1

MANFRE, A.J.; LAHATTE, G.A.; CLIMER, C.R.; MARCOTTE JR, W.R. Seed dehydration and the establishment of desiccation tolerance during seed maturation is altered in the Arabidopsis thaliana mutant atem6-1. Plant and Cell Physiology, v.50, n.2, p.243-253, 2009. http:// pcp.oxfordjournals.org/content/50/2/243.long

MARCOS-FILHO, J. Fisiologia de sementes de plantas cultivadas. Piracicaba: FEALQ, 2005. 495p.

PAMMENTER, N.W.; GREGGAINS, V.; KIOKO, J.I.; WESLEYSMITH, J.; BERJAK, P.; FINCH-SAVAGE, W.E. Effects of differential drying rates on viability retention of recalcitrant seeds of Ekebergia capesis. Seed Science Research, v.8, p.463-471, 1998. http://journals. cambridge.org/action/displayAbstract? fromPage $=$ online $\&$ aid $=1356288$
PORCEL, R.; GÓMEZ, M.; KALDENHOFF, R.; RUIZ-LOZANO, J.M. Impairment of NtAQP1 gene expression in tobacco plants does not affect root colonisation pattern by arbuscular mycorrhizal fungi but decreases their symbiotic efficiency under drought. Mycorrhiza, v.15, p.417-423, 2005. http://link.springer.com/article/10.1007/s00572-005-0346-5

SCANDALIOS, J.G. Oxidative stress: molecular perception and transduction of signals triggering antioxidant gene defenses. Brazilian Journal of Medical and Biological Research, v.38, n.7, p.995-1014, 2005. http://www.scielo.br/pdf/bjmbr/v38n7/v38n7a03.pdf

SCHWEMBER, A.; BRADFORD, K.J. Quantitative trait loci associated with longevity of lettuce seeds under conventional and controlled deterioration storage conditions. Journal of Experimental Botany, v.61, n.15, p.4423-4436, 2010. http://jxb.oxfordjournals.org/content/ early/2010/08/06/jxb.erq248.full.pdf + html

SILVA, D.G.; CARVALHO, M.L.M.; NERY, M.C.; OLIVEIRA, L.M.; CALDEIRA, C.M. Alterações fisiológicas e bioquímicas durante o armazenamento de sementes de Tabebuia serratifolia. Cerne, v.17, p.1-7, 2011. http://www.dcf.ufla.br/cerne/administracao/publicacoes/ m502v17n1o1.pdf

SOUZA, V.C.; BRUNO, R.D.L.A.; ANDRADE, L.A. Vigor de sementes armazenadas de ipê-amarelo Tabebuia serratifolia (Vahl.) Nich. Revista Árvore, v.29, p.833-841, 2005. http:/www.scielo.br/pdf/rarv/v29n6/ a01v29n6.pdf

ZONTA, J.B.; ARAUJO, E.F.; ARAUJO, R.F.; DIAS, L.A.S Diferentes tipos de secagem: efeitos na qualidade fisiológica de sementes de pinhão manso. Revista Brasileira de Sementes, v.33, n.4, p.721-731, 2011. http://www.alice.cnptia.embrapa.br/bitstream/ doc/906656/1/secagemsementespinhaomanso.pdf 